\title{
A Case of Fungal Infection in Onodi Cell with Visual Loss
}

\author{
Jin Hyeok Jeong ${ }^{1}$, Tae Heon Kim ${ }^{1}$, Han Seok Yoo ${ }^{1}$ and Yoon Jung Lee ${ }^{2}$ \\ ${ }^{1}$ Department of Otolaryngology-Head and Neck Surgery, ${ }^{2}$ Ophthalmology, College of Medicine, Hanyang University, Seoul, Korea
}

\section{시력 소실을 동반한 Onodi Cell의 진균 감염 1예}

정진혁 ${ }^{1} \cdot$ 김태헌 $^{1} \cdot$ 유한석 ${ }^{1} \cdot$ 이윤정 ${ }^{2}$

한양대학교 의과대학 이비인후-두경부외과학교실, ${ }^{1}$ 안과학교실 ${ }^{2}$

\author{
Received June 5,2009 \\ Revised July 31,2009 \\ Accepted August 10, 2009 \\ Address for correspondence \\ Jin Hyeok Jeong, MD \\ Department of Otolaryngology- \\ Head and Neck Surgery, \\ College of Medicine, \\ Hanyang University, \\ 17 Haengdang-dong, \\ Seongdong-gu, Seoul 133-791, Korea \\ Tel $+82-31-560-2368$ \\ Fax $+82-31-566-4884$ \\ E-mail ent@hanyang.ac.kr
}

The Onodi cell, which is a posterior ethmoid cell that gets pneumatized far laterally and to some degree superiorly to the sphenoid sinus, is intimately associated with the optic nerve. The problem with most cases of Onodi cells is that acute visual loss may occur in association with a compression to the optic nerve by a mucocele of an Onodi cell. We report, with a review of literature, a case of fungal infection in Onodi cells with acute visual loss in a 71 year-old female patient, who was treated by endoscopic sinus surgery with electrical drill and steroid therapy.

Korean J Otorhinolaryngol-Head Neck Surg 2009;52:776-80

Key Words Optic neuritis · Onodi cell · Aspergillus.

\section{서 론}

시신경염은 시신경의 급성 혹은 아급성의 염증으로 염증 성, 감염성, 탈수질과정(demyelination) 등의 과정을 거쳐 시신경을 침범하여 발생하는 질환으로, 다발성 경화증이 가 장 흔한 원인이며, 그 외 감염, 종양, 육아종, 혈관성 질환 등도 원인이 될 수 있다. ${ }^{1,2)}$

Onodi cell은 후사골동이 접형동의 외상방으로 함기화 되 어 자란 공간으로 시신경과 가까이 위치하게 되며, 보고자에 의해 편차는 있지만 약 8 14\%에서 발견되는 것으로 보고 되어 있다. ${ }^{3-5)}$ Onodi cell에 의한 시력 소실은 대부분 점액 낭종이 발생하여 팽창하면서 시신경을 압박하여 시신경 변 성을 가져와서 유발한다. ${ }^{6)}$

접형동의 진균 감염이나 Onodi cell의 점액낭종에 의한 시 력 소실의 증례는 드물게 보고 되지만, Onodi cell의 진균 감 염에 의한 시신경염은 아직 보고된 바 없다. 저자들은 점액 낭종이 아닌 Onodi cell에 국한된 진균성 부비동염에 의한 시 력 소실 환자를 내시경적 부비동 수술 후 스테로이드로 치료 하여 시력을 회복하였기에 문헌 고찰과 함께 보고하고자 한다.

\section{증 례}

당뇨나 면역저하 등의 기저질환이 없는 71세 여자로 내원 10 일 전부터 우측 시력 감소가 있어 안과에서 시신경염 의 심되어 시행한 MRI상 양측 후사골동 병변이 관찰되고 진 료 도중 갑작스런 시력 소실이 발생하여, 이비인후과로 의뢰 되어 응급 입원하였다(Fig. 1). 비강 내시경 소견상 부비동 염 소견은 전혀 없었다. 입원 당시 안과 검사상 우측은 빛 감지 (light perception) 가 불가능했으며, 좌안 시력은 0.15 로 측정되었다. 우안에서 구심성 동공장애(relative afferent papillary defect, RAPD) 가 관찰되었으나, 양안 모두 안저검사 및 안구 운동은 정상 소견을 보였다. 시유발전위 검사(visual evoked potential, VEP)상 시신경염이 강하게 의심되었다. 안와 CT상 좌측 후사골동에서 팽창되어 보이는 연조직 음영이 관찰되었고, 우측 후사골동에서는 심한 경화 성 골변화를 보이며 내부에 연조직 음영이 보였고(Fig. 2), 이 공간은 접형동의 외상방에 관찰되어 Onodi cell로 판단되 었고(Fig. 3), 시신경 방향의 외측 골벽 결손이 관찰되었다. 이들 좌, 우측의 Onodi cell은 음영의 강도는 달랐으나 서로 

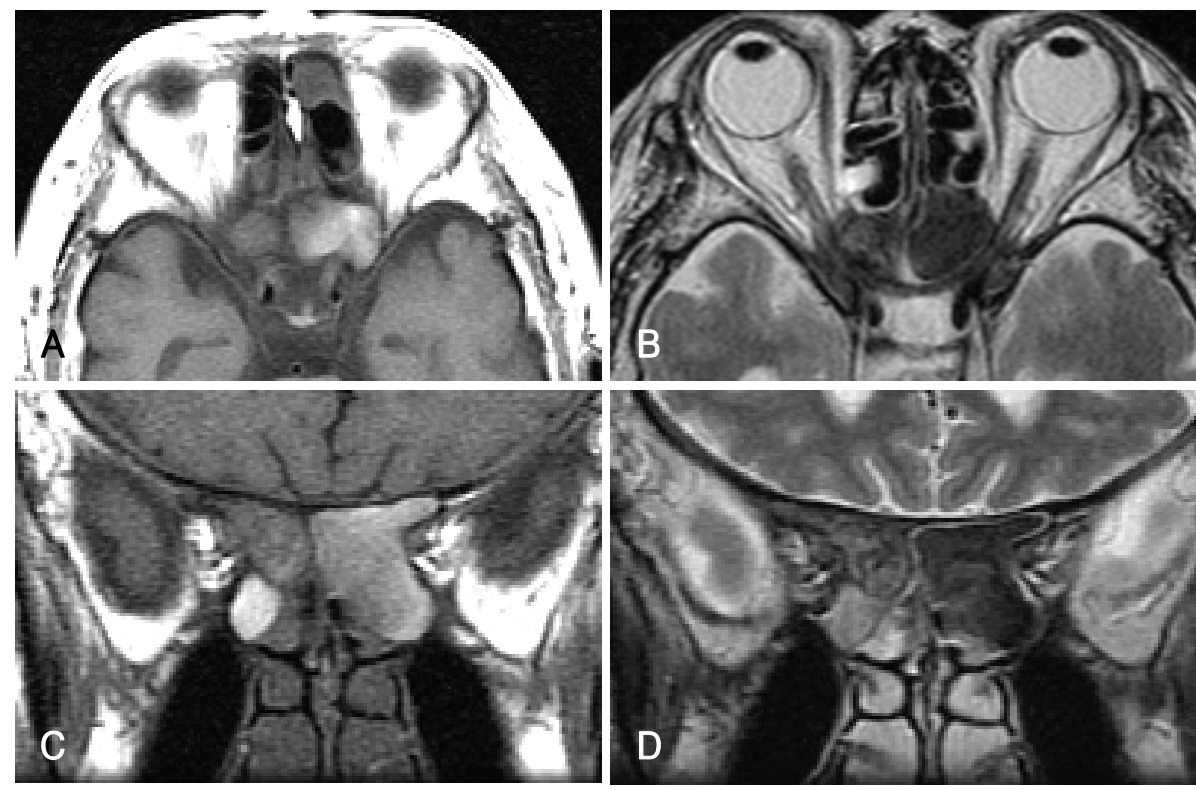

Fig. 1. Preoperative brain MRI. Left posterior ethmoid sinus is filled with heterogenous iso-to high-signal intensity and right posterior ethmoid sinus filled with iso-signal intensity on $T 1$ weighted axial image $(A)$ and coronal image (C). Both posterior ethmoid sinuses are filled with lowsignal intensity on T2 weighted axial image (B) and coronal image (D).
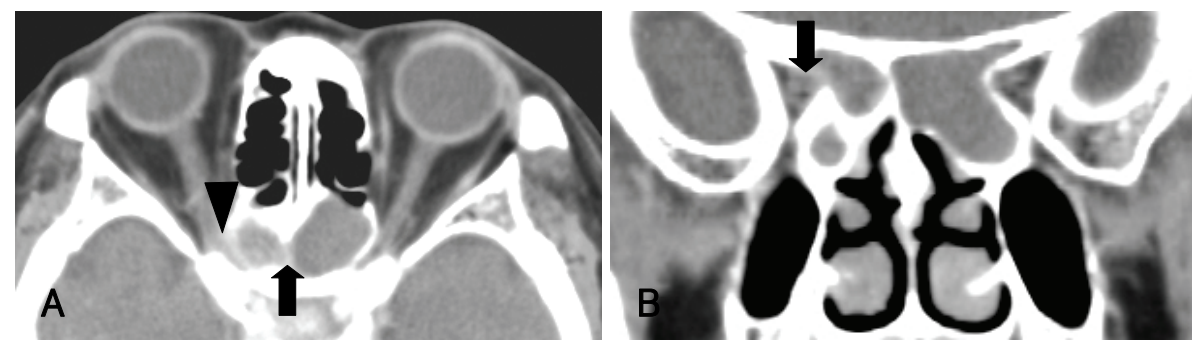

Fig. 2. Preoperative orbital CT. Both posterior ethmoid sinuses are filled with abnormal soft tissue density. Definite bony erosion between right orbital apex and right ethmoid sinus is observed (arrowhead). A bony defect is also seen between both posterior ethmoid sinuses (arrow)(A). Definite bony erosion of lateral wall of right posterior ethmoid sinus is observed on enhanced coronal CT scan (arrow)(B).
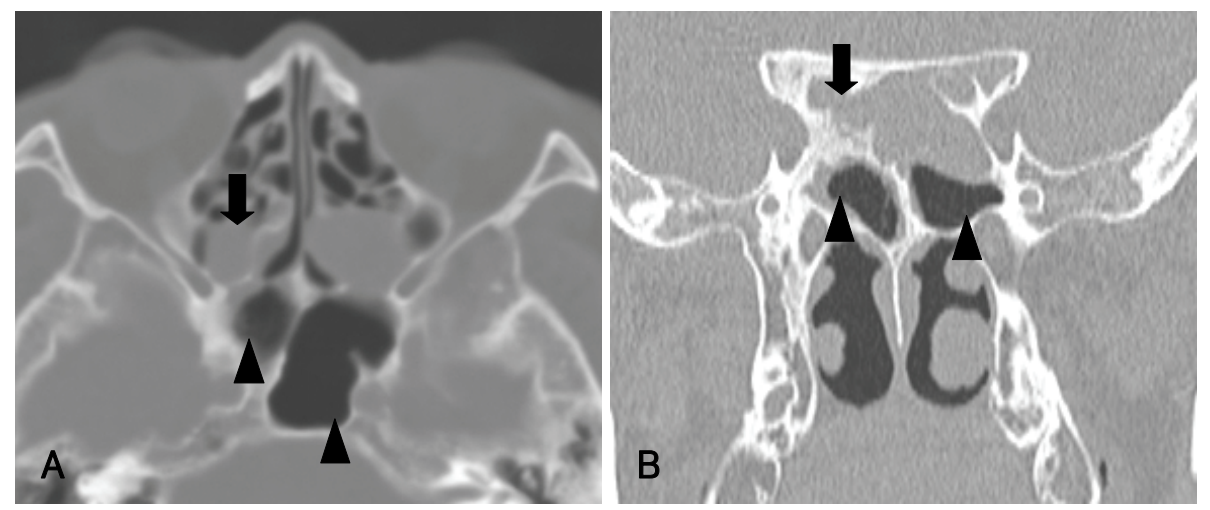

Fig. 3. Onodi cell on CT. Right Onodi cell is filled with soft tissue density (arrow) over the sphenoid sinus (arrowheads) on axial $(A)$ and coronal (B) CT.

교통되어 있는 것으로 보이며, 양측 접형동은 정상 소견이었 다(Fig. 3). 조영 증강시 우측 시신경 주위의 염증 소견을 보 였다.

환자는 입원 당일 응급으로 전신마취하에 부비동 내시경 수술을 시행하였다. 팽창성의 좌측 Onodi cell에서는 진균 감염시 보이는 점도가 높은 진흙같은 노란색의 물질을 제거 하였고, 우측 Onodi cell은 골경화가 심하여 드릴을 이용하 여 후사골동 절제술을 시행 후 안을 꽉 채우고 있는 진균으 로 의심되는 고체상태의 갈색의 물질을 제거하였다(Fig. 4).
우측 안와첨부의 내측벽에서 골부 결손을 확인하였으며 시 신경 주위에 염증성 육아종이 확인되었다(Fig. 4). 술 후 병리 조직학적 검사상 국균증(aspergillosis)으로 진단되 었고 조직침윤 소견은 보이지 않았다(Fig. 5). 술 후 3일째 $50 \mathrm{~cm}$ 에서 손가락 수를 헤아릴 정도의 회복을 보였으며, 술 후 4일째부터 10일간 고용량 스테로이드 치료(Prednisolone $60 \mathrm{mg}$ 5일, $40 \mathrm{mg}$ 3일, $20 \mathrm{mg}$ 3일, $10 \mathrm{mg}$ 1일)를 시행하였다. 술 후 10 일째 $30 \mathrm{~cm}$ 에서 손가락 수를 헤아릴 정도의 시력을 보였고 퇴원하였다. 외래 추적 관찰 중 술 후 

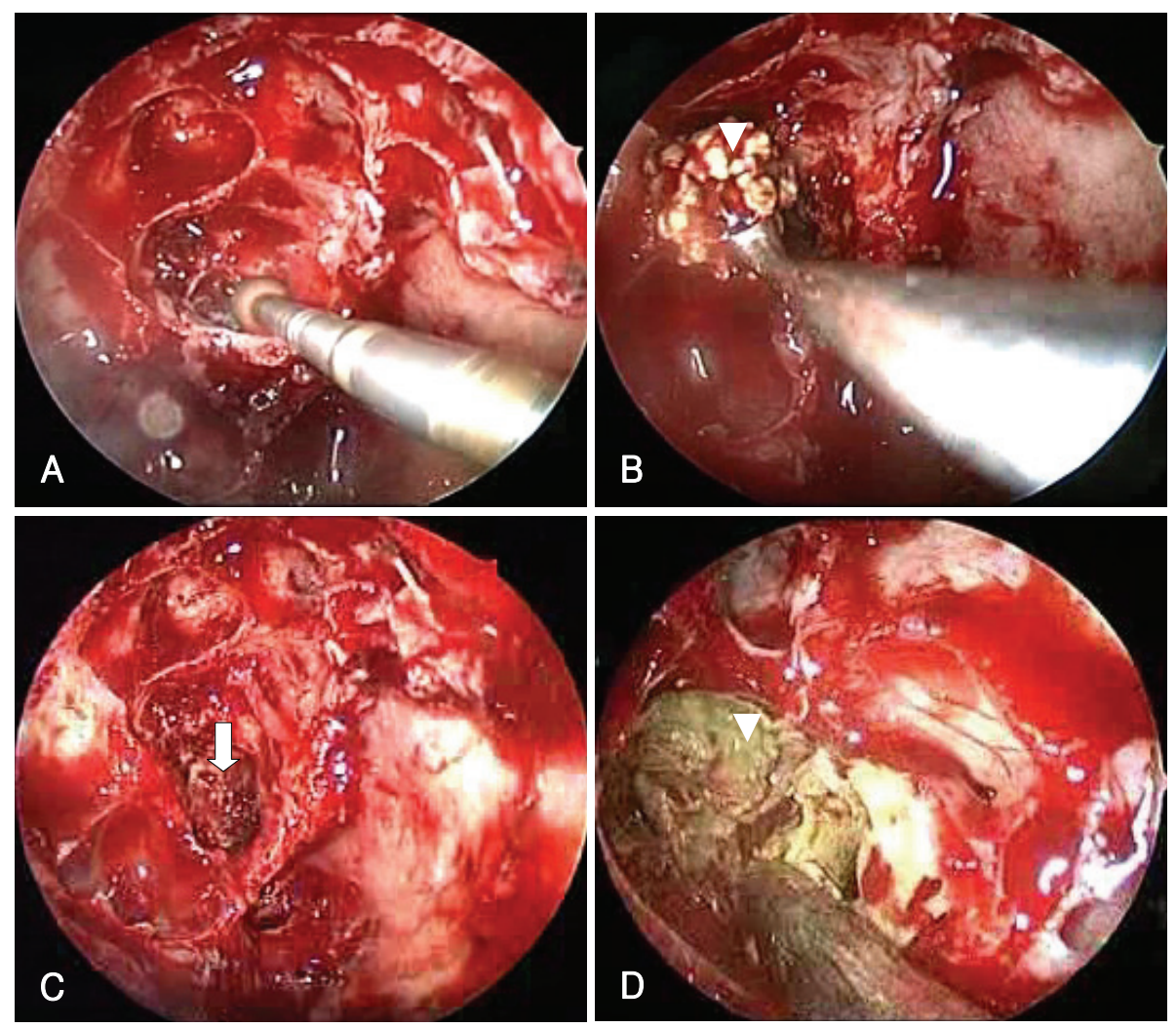

Fig. 4. Operative findings in the right Onodi cell and left posterior ethmoid sinus. Sclerotic right Onodi cell was opened with electrical drill (A). Fungal materials (arrowhead) was noted at right onodi cell (B). Inflammatory granulation tissue (arrow) was observed after removal of right fungal material (C). Yellowish mud-like materials (arrowhead) were observed at left posterior ethmoid sinus (D).
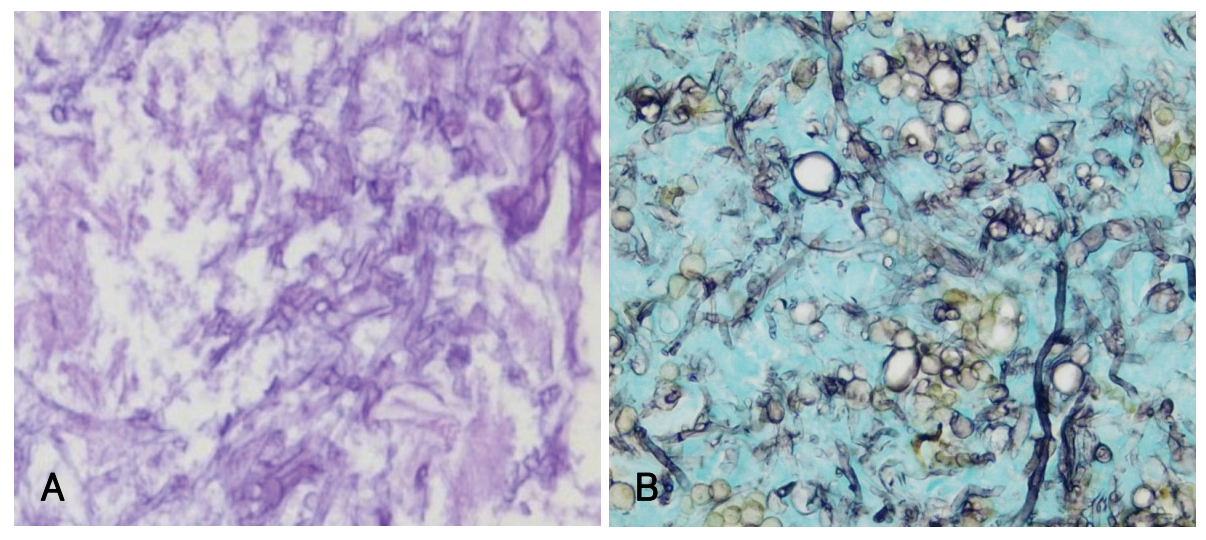

Fig. 5. Biopsy report. PAS (Periodic Acid Stain, $\times 400$ ) stained slide shows aspergillosis with acute and chronic inflammation (A). GMS (Gomori's Methenamine Silver, $\times 400$ ) stained slide shows aspergillosis (B).
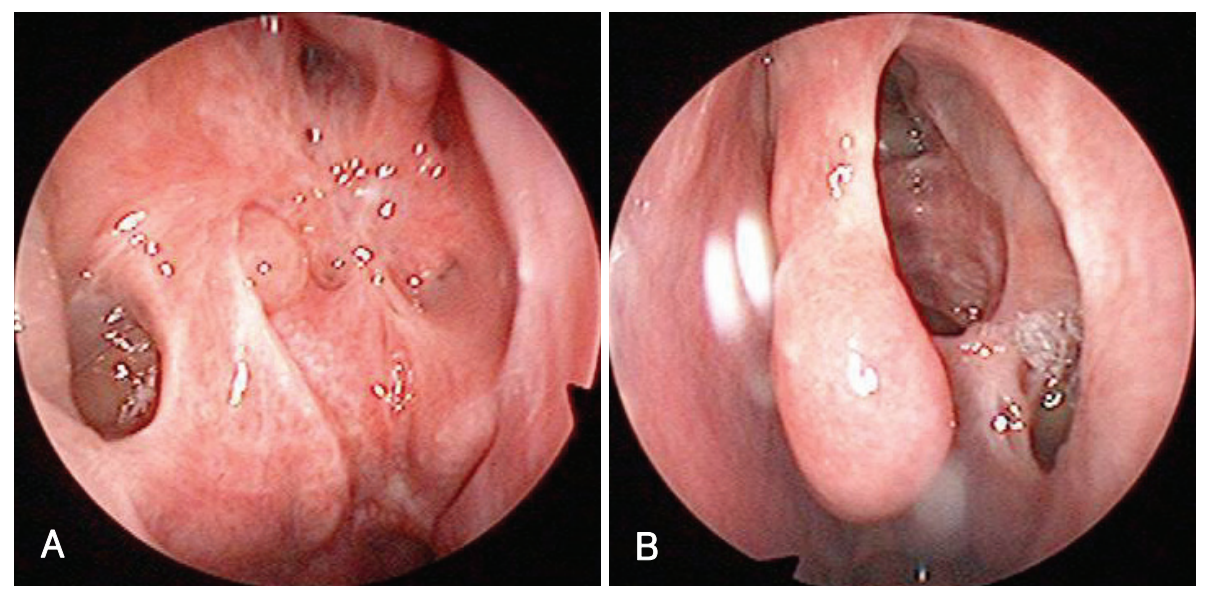

Fig. 6. Postoperative endoscopic findings. After 3 Months, mucosa was completely healed at right $(A)$ and left nasal cavity (B). 
15 일째 다시 빛감지 (light perception) 가 불가능해져서 재 입원 후, 같은 용량의 스테로이드 및 경구 항진균제 (Itraconazole) 치료를 시행하였다. 술 후 17 일째 다시 손의 움직 임을 감지하고, 18 일째 $50 \mathrm{~cm}$ 에서 손가락 수를 헤아릴 수 있었고, 29 일째 우측 시력이 0.02 로 퇴원하였다. 약한 우 안의 시력 저하가 다시 관찰되어 술 후 43 일째 경구 항진균 제는 중단하였고, 저용량 스테로이드 $(15 \mathrm{mg})$ 를 7일간 사용 하였다. 술 후 99일째 시행한 비강 내시경 소견상 수술부 위는 재발 소견 없이 양호한 경과를 보였으며(Fig. 6), 시력 검사상 우안의 나안 시력은 0.3 , 교정 시력은 0.5 로 관찰되 었고 구심성 동공장애는 아직 남아있었으며, 술 후 5 개월째 우안의 나안 시력은 0.2 , 교정 시력은 0.6 으로 측정되었고, 구심성 동공장애도 소실되었다.

\section{고 찰}

Onodi cell은 접형동의 외상부에 위치하는 후사골동봉소 중 가장 후방에 위치하는 봉소로서, 대개 Onodi cell 내측 하방으로 접형동이 존재하며 바로 외측으로 시신경이 주행 하며, 내경동맥이 근거리에 위치한다. ${ }^{3-5,7)}$ 부비동 내시경 수 술시 Onodi cell에 대한 주의 없이 후사골동 제거술을 시 행할 경우 시신경 손상을 줄 수 있어 중요한 의미를 갖는다. 마찬가지로 보통 시신경이 지나가는 접형동의 염증이 아니 라 Onodi cell의 염증으로도 시신경 염증이 발생할 수 있다 는 것을 고려해야 하며 수술적 치료시 주의하여야 한다.

시신경염은 시신경의 급성 혹은 아급성 염증으로 구후신 경염(retrobulbar neuritis)이 가장 흔한 형태로 본 증례 에서도 안저 검사상 정상소견을 보이는 구후신경염이었다. 시신경염의 진단은 정상적인 유리체방(vitreous chamber) 의 소견을 보이면서 대개 1 주 이상은 지속되지 않는 비교 적 갑작스러운 시력감소, 구심성 동공장애, 안구 운동시 발생 하는 동통 등의 소견이 있을 때 가능하다. 시유발전위검사, 뇌자기공명영상 등이 도움이 된다. ${ }^{1,2,8}$

시신경염의 원인으로는 다발성경화증이 가장 흔하고 약 $50 \%$ 에서는 원인을 모르는 경우도 있으며 부비동염에 의한 경우는 드문 것으로 알려져 있다. ${ }^{1,2,9-12)}$ 특히 안와 내벽의 전방부에서는 지판과 골막이 얇으나 후방부는 두꺼워 상악 동염이나 사골동염에 의한 안와 감염보다 후방의 후사골동, 접형동에 의한 안와첨 증후군이 훨씬 드물다. 진균성 부비 동염이 시신경염을 일으키는 기전으로 부비동내의 염증에 의한 직접전파가 가장 흔한 경로이며, 부비동의 골벽 결손 이 있을 때 더 흔히 일어날 수 있다. ${ }^{13)}$ 그 외 신경의 압박이 나 염증 부산물이 정맥이나 림프관을 통해 시신경으로 유입
되는 경우도 원인으로 보고되고 있다. ${ }^{14)}$ 본 증례는 Onodi cell에 진균성 부비동염이 발생한 후 안와골벽 결손 부위로 의 염증의 직접적인 파급으로 발생하였다고 생각된다.

일반적인 부비동염에 의한 시신경염의 치료로는 항생제, 스테로이드, 부비동 수술 등을 이용하여 왔으며, 이중 수술 적 처치가 가장 중요한 요소로 생각된다. ${ }^{14)}$ 진균성 부비동 염의 경우에는 균구의 제거와 환기 및 배출이 가장 중요하 며 침윤성인 경우 Amphotericin B 등의 항진균제 사용이 고려될 수 있으며 시신경 염증의 경우 고용량의 스테로이드 가 시력 호전에 필수적이다. 본 증례에서는 내시경적 부비 동 수술을 통하여 진균구를 제거하고, 인접 점막조직의 조 직검사를 시행하였고, 비침윤성이라 술 후 스테로이드 치료 만으로도 양호한 경과를 보여 항진균제를 초기에 사용하지 않았지만, 다시 시력소실이 발생하여 병리 소견으로도 알 수 없는 미세 침윤도 배제할 수 없어 항진균제를 사용하였 다. 그러나 항진균제 사용 중 다시 시력 저하가 발생해 수술 후에 발생한 시력저하는 진균에 의한 것이 아닌 것으로 생 각되고 환자의 면역기능이 정상이라 항진균제는 중지하였 으며 스테로이드로 시신경의 회복을 도모하였다. 결과적으 로 볼 때 본 증례에서 수술 전, 후 시력 저하를 일으킨 시신 경염은 진균의 직접 침윤에 의한 것보다는 진균 감염에 의 한 골파괴를 일으키고 이를 통한 진균구 주위의 육아조직과 그 염증의 파급으로 보는 것이 타당할 것 같다.

시신경염의 예후는 유발 원인에 따라 차이가 있지만, 대부 분 예후가 좋은 것으로 보고되었다. ${ }^{15)}$ 탈수질 과정에 의한 시신경염은 $75 \%$ 에서 시력이 회복 가능하며, 이환 기간 중 광감응이 없을 경우에도 회복될 수 있다. 감염에 의한 시신경 염은 원인을 치료할 때 대부분 회복되는 것으로 보고되어 있 다. ${ }^{15)}$ 본 증례에서도 이환 기간 중에는 무광각 상태였으나, 시신경염의 원인인 진균 감염을 내시경을 이용한 수술적 방 법으로 제거한 후, 스테로이드로 시력을 회복하였다. 그러나 부비동 내시경 수술 후 염증이나 육아조직이 완전히 사라지 는 2 3개월 동안은 일시적으로 스테로이드에 반응하여 시력 이 호전되더라도 남은 염증과 육아조직에 의해 다시 시력이 나빠질 수 있어 재투여가 필요하였으며, 염증과 육아조직이 완전히 소실된 후에는 시력은 더 이상 나빠지지 않았다.

접형동이 아닌 Onodi cell에서도 시신경의 근접성 때문에 진균성 부비동염에 의한 시신경염이 발생할 수 있음을 알 고 적절한 수술적 치료와 약물치료로 시력을 호전시키도록 해야 한다.

\section{REFERENCES}

1) Kanski JJ. Clinical ophthalomology. 4th ed. Butterworth-Heinemann: 
reed educational and professional publishing;1999. p.590-3.

2) Beck RW. Inflammatory optic neuropathies and neuroretinitis. In: Janoff M, Duker JS, editors. Opthalmology. 2nd ed. London: Mosby; 1999. p.1161-4.

3) Driben JS, Bolger WE, Robles HA, Cable B, Zinreich SJ. The reliability of computerized tomographic detection of the Onodi (Sphenoethmoid) cell. Am J Rhinol 1998;12 (2):105-11.

4) Jones NS, Strobl A, Holland I. A study of the CT findings in 100 patients with rhinosinusitis and 100 controls. Clin Otolaryngol 1997;22 (1): 47-51.

5) Stammberger HR, Kennedy DW. Paranasal sinuses: anatomic terminology and nomenclature. The Anatomic Terminology Group. Ann Otol Rhinol Laryngol 1995;167:7-16.

6) Kitagawa K, Hayasaka S, Shimizu K, Nagaki Y. Optic neuropathy produced by a compressed mucocele in an Onodi cell. Am J Ophthalmol 2003;135(2):253-4

7) Mecit Kantarci, R. Murat Karasen, Fatih Alper, Omer Onbas, Adnan Okur, Adem Karaman. Remarkable anatomic variations in paranasa sinus region and their clinical importance. Eur J Radiol 2004;50 (3) :296-302
8) Kim CH, Cho MJ, Kim HJ, Ahn JH. A case of optic neuritis secondary to fungal sphenoid sinusitis. Korean J Otolaryngol -Head Neck Surg 2004;47 (6):594-7.

9) Rothstein J, Maisel RH, Berlinger NT, Wirtschafter JD. Relationship of optic neuritis to disease of the paranasal sinuses. Laryngoscope 1984;94 (11 pt 1):1501-8.

10) Welsh LW, Welsh JJ. Orbital complications of sinus disease. Laryngoscope 1974;84 (5):848-56.

11) Kronschnabel EF. Orbital apex syndrome due to sinus infection. Laryngoscope 1974;84 (3):353-71.

12) Chandler JR, Langenbrunner DJ, Steven ER. The pathogenesis of orbital complications in acute sinusitis. Laryngoscope 1970;80 (9) :141428.

13) Kountakis SE, Maillard AA, Stiernberg CM. Optic neuritis secondary to sphenoethmoiditis: surgical treatment. Am J Otolaryngol 1995;16 (6) :422-7.

14) Awerbuch G, Labadie EL, Van Dalen JT. Reversible optic neuritis secondary to paranasal sinusitis. Eur Neurol 1989;29 (4) :189-93.

15) Jack JK. Neuro-ophthalmology. In: clinical ophthalmology: a systemic Approach. $5^{\text {th }}$ ed. Butterworth Heinemann;2003. p.601-3. 